\title{
GAYA BAHASA KIASAN \\ DALAM NOVEL HATI SUHITA KARYA KHILMA ANIS DAN RELEVANSINYA SEBAGAI BAHAN AJAR DI SMA
}

\author{
(Figurative Language in Khilma Anis's Hati Suhita \\ and Its Relevances as Teaching Materials in High School) \\ Aulia Normalita \\ Universitas Sebelas Maret Surakarta \\ Jalan Ir. Sutami 36, Kentingan, Surakarta, Jawa Tengah 57126 \\ Pos-el: aulianormalita277@gmail.com
}

(Naskah Diterima 19 Maret 2021—Direvisi 23 Juli 2021—Disetujui 20 September 2021)

\begin{abstract}
Hati Suhita which is set in Java contains some philosophical and figurative languages. This research aims to describe some figurative languages of Khilma Anis's Hati Suhita and its relevance as a teaching material in high school. This is a descriptive qualitative research. The research data are in the form of words or sentences. The source of the data is the novel Hati Suhita and high school syllabus. The data collection techniques are read and note-taking techniques. The data analysis is then applied to the lists of figurative style passage dialogue using content analysis. The results showed that in the novel there were 32 styles of figurative languages. There are 6 data in the form of simile, 1 metaphorical, 12 personifications, 6 allusions, 6 eponymous data, and 1 data in the form of irony. Style that dominates the invention was the personification. Overall, the distinctive figurative language styles used in various forms of parables and comparisons in the novel are Javanese puppet characters and proverbs. This is unique in the discovery of language styles in this study. The results of the analysis of the language style in this novel have relevances as teaching materials with three $\mathrm{KD}$, among them found in KD 3.9.4.9, 3.4.4.4, 3.9.4.9 of XI and XII degrees.
\end{abstract} Keywords: figurative language style, novel Hati Suhita, relevance of learning

\begin{abstract}
Abstrak
Dalam novel Hati Suhita ditemukan gaya bahasa kiasan yang sarat akan budaya dan filosofi Jawa yang terkandung di dalamnya. Penelitian ini bertujuan untuk mendeskripsikan gaya bahasa kiasan yang terdapat dalam novel Hati Suhita karya Khilma Anis dan relevansinya sebagai bahan ajar di SMA. Penelitian ini bersifat deskriptif kualitatif. Data berupa kata atau kalimat yang menunjukkan gaya bahasa kiasan. Sumber data berupa novel Hati Suhita dan silabus bahasa Indonesia pada jenjang SMA. Teknik pengumpulan data menggunakan teknik simak dan catat, pencatatan dilakukan untuk menuliskan petikan dialog yang mengandung gaya bahasa kiasan. Teknik analisis menggunakan analisis isi. Hasil analisis menunjukkan bahwa dalam novel tersebut terdapat 32 gaya bahasa kiasaan, yaitu 6 data gaya bahasa simile atau persamaan, 1 data metafora, 12 data personifikasi, 6 data alusi, 6 data eponimi, dan 1 data ironi. Gaya bahasa kiasan yang mendominasi adalah personifikasi. Kekhasan gaya bahasa kiasan yang digunakan dalam berbagai bentuk perumpamaan dan perbandingan pada novel tersebut adalah tokoh-tokoh pewayangan dan peribahasa Jawa. Hal tersebut merupakan keunikan dalam penelitian ini. Hasil analisis gaya bahasa dalam novel ini memiliki relevansi
\end{abstract}


sebagai bahan ajar dengan tiga KD, di antaranya terdapat pada KD 3.9.4.9, 3.4.4.4, 3.9.4.9. yang terdapat pada kelas XI dan XII.

\section{Kata kunci: gaya bahasa kiasan, novel Hati Suhita, relevansi pembelajaran}

\section{PENDAHULUAN}

Karya sastra tercipta sebagai media hiburan dan pengetahuan yang dapat dinikmati oleh pembaca. Terlahirnya karya sastra sebagai hiburan menjadikan para penulis menuangkannya dengan bahasa figuratif sebagai daya tarik agar pembaca menikmati cerita yang disajikan. Melalui bahasa figuratif pembaca akan diajak menjelajahi cerita dengan bahasa yang tidak biasa. Ardiansyah menyatakan bahwa melalui karya sastra penulis memberikan pemahaman, pengalaman, dan wawasan kepada pembaca atau pendengar dengan memenuhi kebutuhan estetis melalui karya sastra yang ditulis (Ardiansyah, dkk, 2020).

Pada karya sastra novel yang memiliki deskripsi lebih banyak dibanding puisi dan cerpen, memungkinkan penulis untuk memberikan sentuhan estetis berupa gaya bahasa. Penggunaan gaya bahasa dapat digunakan untuk menghidupkan dan memberikan bumbu pada tulisan agar lebih indah dan terkesan hidup.

Gaya bahasa berperan penting dalam menghidupkan cerita yang disajikan. Penggunaan gaya bahasa secara khusus, seperti bahasa kiasan, mampu memengaruhi pembaca untuk menemukan ide dan maksud pengarang (Lalanissa \& Nazaruddin, 2017).

Menurut Ratna, gaya bahasa termasuk dalam ranah kajian stilistika (Normalita, A., \& Hasanah, 2020). Stilistika atau stylistic adalah ilmu tentang gaya, sedangkan stil atau style ialah cara-cara yang khas. Berdasarkan penjabaran tersebut, gaya bahasa berfungsi sebagai ungkapan yang meggunakan bahasa tertentu agar tulisan yang dituangkan tersampaikan secara maksimal kepada pembaca. Abrams (2009) menambahkan bahwa stile atau style adalah bentuk pengucapan bahasa dalam prosa atau cara pengarang dalam mengungkapkan sesuatu yang akan dikemukakan. Stile ditandai dengan pilihan kata, stuktur kalimat dan bentuk-bentuk bahasa figuratif yang indah. Selain itu, menurut Tarigan (2013) gaya bahasa adalah bentuk retorik, yakni penggunaan katakata dalam menulis atau berbicara untuk meyakinkan atau memengaruhi penyimak dan pembaca.

Gaya bahasa hadir dengan katakata yang indah, kata-kata yang dapat menimbulkan konotasi tertentu sekaligus dapat mewakili perasaan pengarang agar dapat memengaruhi pembaca. Selain kreativitas yang ada di dalamnya, novel dapat dijadikan sebagai bahan ajar untuk mendukung proses pembelajaran di sekolah.

Kreativitas penulis akan terlihat dari bahasa yang dituangkan. Ada beragam gaya bahasa kiasan yang digunakan dalam novel, di antaranya gaya bahasa perbandingan, penegasan, pertentangan, dan sebagainya. Gaya bahasa dan kesusastraan berkaitan erat. Salah satunya dalam novel. Representasi kehidupan banyak dituangkan pengarang melalui novel, baik berupa novel sosial, politik, keagamaan, maupun kebudayaan.

Novel terlahir sebagai bagian dari bentuk sastra yang mengandung realita berupa peristiwa dan perilaku dalam kehidupan masyarakat (Febrianto, D. \& Anggraini, 2019) . Peristiwa yang terjadi dalam kehidupan tidak terlepas dari filsafat budaya yang berkembang dalam wilayah tersebut. Sama halnya 
dengan novel yang berisi cerita mengenai kebudayaan yang terjadi dalam realita kehidupan.

Tidak semua karya sastra merupakan representasi kehidupan penulis. Ada juga yang merupakan hasil dari pengamatan, imajinasi pengarang, atau murni karangan berbentuk fiksi yang ditulis dengan gaya bahasa yang indah dan menarik.

Penelitian yang relevan dengan topik ini dilakukan oleh Pitriyani dengan judul "Gaya Bahasa Kiasan dalam Novel Bulan Karya Tere Liye". Tujuan penelitian tersebut ialah mendeskripsikan gaya bahasa kiasan dalam novel Bulan karya Tere Liye. Ditemukan 73 gaya bahasa kiasan yang terdiri atas 37 persamaan atau simile, 7 metafora, 21 personifikasi atau prosopopoeia, 6 ironi, dan 2 antonomasia (Pitriyani, 2017).

Penelitian lain yang juga relevan dilakukan Abadiyah yang berjudul Resolusi Konflik Perjodohan dalam Novel Hati Suhita Karya Khilma Anis. Tujuan penelitian yang dilakukan Abadiyah ialah mengidentifikasi wujud konflik dan resolusi konflik perjodohan ditinjau dari psikologi sastra Kajian yang digunakan adalah psikologi sastra. Hasil penelitian berupa konflik internal dan eksternal. Konflik internal di antaranya terdiri atas kecewa, diabaikan, tidak dianggap, dan berpurapura. Adapun permasalahan eksternal berupa cemburu terhadap tokoh Rengganis di tengah pernikahan Gus Birru dan risau akan kepergian Rengganis. Resolusi yang ditemukan dalam novel tersebut adalah tokoh Gus Birru meminta maaf kepada Alina Suhita setelah apa yang terjadi dalam rumah tangganya (Abadiyah, 2020).

Penelitian Hawa yang berjudul Analisis Tokoh dan Aspek Spiritual Quotient Novel Hati Suhita Karya Khilma Anis juga relevan dengan tema ini. Adapun tujuan dari penelitian tersebut ialah mendeskripsikan tokohtokoh novel itu dan mendeskripsikan aspek-aspek spiritual quotient (kecerdasan spiritual) yang terdapat dalam novel Hati Suhita karya Khilma Anis (Hawa, 2020).

Teori yang digunakan adalah teori Zohar dan Marshal yang terdiri atas kemampuan bersikap fleksibel, tingkat kesadaran diri yang tinggi, kemampuan menghadapi dan memanfaatkan penderitaan, kemampuan untuk menghadapi dan melampaui rasa sakit, kualitas hidup yang diilhami oleh visi dan misi, dan kecenderungan untuk bertanya serta mencari jawaban yang mendasar. Hasil penelitian menunjukkan kisah cerita tokoh utama dan beberapa tokoh tambahan mengandung enam aspek spiritual quotient yang terdiri dari tokoh Alina Suhita, Gus Birru, Rengganis, dan Kang Dharma.

Persamaan dan perbedaan penelitian ini dengan penelitian terdahulu terletak pada kajian dan objek yang digunakan. Persamaannya dengan penelitian pertama ialah berfokus pada stilistika, yakni gaya bahasa kiasan yang terdapat dalam novel, sedangkan perbedaannya terletak pada objek kajian yang digunakan, yakni Hati Suhita dan Bulan. Persamaan penelitian ini dengan penelitian kedua dan ketiga terdapat pada objek kajiannya yang mengkaji novel Hati Suhita kaya Khilma Anis. Pembedanya adalah kajian yang digunakan. Penelitian kedua menggunakan kajian psikologi sastra, sedangkan yang kedua menggunakan aspek-aspek spiritual quotient (kecerdasan spiritual) milik Zohar dan Marshal.

Berdasarkan penjelasan di atas dapat disintesiskan bahwa penelitian ini memiliki nilai kebaruan. Selain itu, penelitian ini berkaitan dengan salah 
satu bahan ajar di sekolah, yakni novel. Media pembelajaran dari novel dapat diambil dari sisi amanat atau pesan cerita di dalamnya.. Selain itu dapat diambil juga dari keunikan-keunikan yang menonjol dengan novel yang lain dan dapat dilihat dari pola bahasa yang digunakan, yakni berupa gaya bahasa dalam suatu novel. Pembelajaran bahasa dan sastra Indonesia salah satunya memuat gaya bahasa. Gaya bahasa yang terdapat dalam novel tersebut dapat dikenalkan, diajarkan, bahkan dipraktikkan siswa di luar atau di dalam kelas.

Gaya bahasa kiasan adalah gaya bahasa yang tidak secara langsung menunjukkan makna yang sesungguhnya. Bahasa yang digunakan merupakan analogi terhadap sesuatu yang akan disampaikan oleh penulis atau pembicara.

Kiasan disebut juga dengan gaya bahasa, yakni penggunaan bahasa dalam bentuk perbandingan atau perumpamaan (Sardani, R., \& Indriani, 2018). Pada umumnya kiasan banyak digunakan dalam karya sastra, tetapi tidak menutup kemungkinan kiasan digunakan dalam bahasa sehari-hari. Sejatinya, kiasan dapat ditemukan dalam berbagai bentuk penggunaan bahasa. Gaya bahasa kiasan dimaknai sebagai gaya bahasa yang maknanya tidak dapat ditafsirkan sesuai dengan makna kata-kata yang membentuknya (Keraf, 2008).

Keraf membagi gaya bahasa kiasan menjadi dua belas gaya bahasa, di antaranya persamaan atau simile, metafora, personifikasi, alusi, eponim, epitet, sinekdoke, metonimi, hipalase, ironi, inuendo, dan pun atau paronomasia. Gaya bahasa persamaan atau simile adalah gaya bahasa berupa perbandingan secara eksplisit karena secara langsung menyatakan sesuatu yang sama dengan hal lain yang berlainan. Simile ditandai dengan kata seperti, sama, bagaikan, bagaikan, laksana. Simile berkaitan dengan konteks. Nurgiyantoro menambahkan bahwa simile berkonsep persamaan sifat pertama dinyatakan lebih dulu kemudian persamaan sifat kedua baru disebutkan di belakang (Nurgiyantoro, 2010).

Metafora ialah gaya bahasa kiasan berupa perbandingan dua hal secara langsung dalam bentuk singkat. Metafora termasuk gaya bahasa perbandingan langsung yang tidak menggunakan kata pembanding. Dalam hal ini Nurgiyantoro menjelaskan bahwa gaya bahasa metafora adalah gaya bahasa perbandingan yang memiliki sifat tidak secara langsung dan implisit.

Ketiga, personifikasi, adalah gaya bahasa kiasan yang membandingkan benda-benda mati atau benda yang tidak bernyawa seolah-olah memiliki sifat kemanusiaan. Personifikasi juga disebut sebagai penginsanan sifat-sifat insani kepada yang tidak bernyawa, binatang, angan, atau ide yang abstrak. Secara singkat Nurgiyantoro mengungkapkan bahwa personifikasi dapat dipandang sebagai gaya bahasa yang mendasarkan diri pada adanya sifat-sifat perbandingan dan persamaan.

Keempat, alusi, adalah gaya bahasa berupa acuan yang menyugestikan kesamaan antara orang, tempat, dan peristiwa. Alusi dapat berupa referensi yang eksplisit atau implisit terhadap peristiwa, tokoh, mitologi, tempat dalam kehidupan nyata atau karya sastra.

Selanjutnya, yang kelima adalah eponim, yakni menghubungkan nama orang dengan sifat tertentu. Keenam, epitet, adalah gaya bahasa yang memiliki acuan yang menyatakan suatu ciri khas seseorang atau suatu hal. Acuan tersebut berupa frasa deskriptif 
untuk menggantikan atau menjelaskan nama seseorang atau barang.

Menurut Nurgiyantoro, sinekdoke berasal dari bahasa Yunani synekdechsthai yang memiliki arti menerima bersama-sama. Gaya bahasa tersebut dimaknai sebagai gaya bahasa pertautan atau menggunakan sebagian untuk menyatakan keseluruhan. Kemudian, ditambahkan oleh Keraf, sinekdoke adalah gaya bahasa yang berupa gaya bahasa figuratif untuk menyebutkan sebagian dari sesuatu untuk menyatakan keseluruhan (pars pro toto) dan menyebutkan keseluruhan untuk menyatakan sebagian (totem pro parte).

Metonimi adalah gaya bahasa yang mempergunakan suatu kata untuk menyatakan suatu hal lain karena kata tersebut memiliki hubungan yang sangat dekat. Nurgiyantoro menambahkan bahwa metonimi adalah gaya bahasa kiasan yang menunjukkan adanya pertautan atau pertalian yang dekat.

Kesembilan, hipalase, adalah gaya bahasa yang mempergunakan suatu kata tertentu untuk menerangkan sebuah kata yang seharusnya digunakan untuk kata lain. Sementara itu, ironi adalah gaya bahasa kiasan yang menyatakan makna bertentangan dengan maksud mengejek atau mengolok-olok. Kemudian yang kesebelas adalah inuendo, yaitu gaya bahasa berupa sindiran dengan mengecilkan kenyataan yang sebenarnya. Terakhir adalah gaya bahasa pun atau paronomasia, yaitu gaya bahasa permainan kata yang berdasarkan kemiripan bunyi, tetapi terdapat perbedaan besar pada maknanya.

Penelitian ini mengambil novel sebagai objek kajiannya. Adapun fokus kajian yang digunakan ialah stilistika dengan spesifikasi gaya bahasa kiasan. pada novel Hati Suhita karya Khilma
Anis. Novel Hati Suhita menceritakan kisah cinta segitiga dan seputar dunia pesantren. Dalam cerita tersebut tokoh yang bernama Gus Birru dijodohkan dengan Alina Suhita, seorang putri kiai besar yang cerdas dan piawai mengurus pesantren. Konflik yang ditunjukkan dalam cerita tersebut adalah rasa cinta Gus Birru yang masih mencintai kekasihnya, Ratna Rengganis. Kesedihan dan kemalangan tokoh Suhita atau Alina Suhita inilah yang kemudian dituliskan dengan gaya bahasa kiasan yang sedih dan merana. (Anis, 2019).

Dalam novel tersebut ditemukan banyak sekali gaya bahasa kiasan yang digunakan. Keunikan yang menjadikan peneliti tertarik adalah bahasa kiasan yang digunakan kental dengan kiasan cerita Jawa, baik seputar tokoh pewayangan maupun prinsip orang Jawa. Hal itu dilatarbelakangi oleh kehidupan pribadi pengarang yang menyukai dunia pewayangan.

Penelitian ini bertujuan menyelisik lebih dalam gaya bahasa kiasan yang digambarkan pengarang untuk menarik pembaca ke dalam tulisannya dan relevansinya sebagai bahan ajar di SMA. Tujuannya ialah agar para pendidik memanfaatkan novel sebagai bahan ajar yang berguna dan mampu meningkatkan literasi siswa.

Relevansinya dengan pendidikan, novel yang dikaji dapat digunakan sebagai bahan ajar yang sesuai dengan KD. Salah satunya adalah KD 3.4 menganalisis kebahasaan cerita atau novel sejarah, 4.4 menulis cerita sejarah pribadi dengan memperhatikan kebahasaan. KD tersebut dapat menggunakan novel sebagai bahan ajar untuk menelisik kebahasaan yang ada di dalamnya. 


\section{METODE PENELITIAN}

Jenis penelitian ini ialah deskriptif kualitatif, yakni mendeskripsikan semua gaya bahasa kiasan yang terdapat dalam novel Hati Suhita kemudian diklasifikasikan sesuai dengan teori yang digunakan.

Menurut Moleong definisi kualitatif secara holistik dapat dideskripsikan dalam bentuk kata-kata, dan bahasa pada konteks alamiah dan memanfaatkan metode yang alamiah (Moleong, 2007).

Data penelitian berupa kata atau kalimat yang menunjukkan gaya bahasa kiasan yang terdapat dalam novel Hati Suhita dan kelayakannya dikorelasikan sebagai bahan ajar di SMA. Sumber data berupa novel karangan Khilma Anis yang berjudul Hati Suhita dan silabus Bahasa Indonesia pada jenjang SMA. Teknik analisis menggunakan analisis isi. Selanjutnya teknik pengumpulan data menggunakan teknik simak dan catat.

\section{PEMBAHASAN}

Berikut diuraikan berbagai gaya bahasa yang ditemukan dalam novel Hati Suhita.

\section{Gaya Bahasa Simile}

Terdapat enam data gaya bahasa simile yang ditampilkan sebagai berikut.

\section{Data 1}

"Mungkin beginilah perasaan Prabu Duryudana yang merana. Istrinya, banowati hanya mencintai arjuna. Mungkin seperti inilah hancurnya hati Prabu Duryudana mengetahui banowati memberikan tubuhnya untuk Arjuna musuhnya. Meski aku perempuan, dan prabu duryudaya laki-laki aku bisa merasakan pedihnya diabaikan". (Anis, 2019: 7).

Data (1) berupa simile, yakni membandingkan sesuatu yang berlainan, tetapi dianggap sama. Gaya bahasa simile dalam petikan dialog di atas ditunjukkan oleh penggunaan kata seperti yang diibaratkan persamaan dan perbandingan. Tokoh Suhita menyamakan keadaan hatinya dengan Prabu Duryudana yang merana sebab diabaikan istrinya sendiri, yakni Banowati. Hal tersebut menjadikan Suhita merasa bernasib malang seperti yang dirasakan oleh Prabu Duryudana. Sekalipun dalam dialog tersebut yang ditunjukkan adalah laki-laki dan disamakan dengan perempuan, nasib terabaikan yang dialami keduanya mampu menyamakan hal yang berbeda. Esensi yang dimunculkan adalah hal mutlak yang dirasakan keduanya, bukan pada eksistensi laki-laki dan perempuan.

\section{Data 2}

"Dulunya kupikir kisah cinta kami akan seperti bagus burham dengan istrinya raden ajeng gombang. Mereka berdua dijodohkan sejak kecil tapi mereka saling mencitai dan saling menginginkan sejak awal". (Anis, 2019: 69).

Data (2) selanjutnya mengandung dua gaya bahasa kiasan. Pertama adalah gaya bahasa alusi dan kedua adalah gaya bahasa simile. Gaya bahasa alusi yakni majas yang menggunakan ungkapan, peribahasa, atau pantun. Dalam petikan dialog di atas tokoh Suhita mengatakan bahwa dahulu ia berpikir cintanya akan seperti Bagus Burham dan Ajeng Gombang yang dijodohkan sejak kecil, tetapi sudah saling menginginkan sejak awal. Kalimat tersebut dimaknai sebagai 
ungkapan tokoh agar kelak seperti tokoh lain, yakni Bagus Burham. Namun, keadaan justru membalikkan semuanya. Oleh sebab itu, ungkapan berupa harapan yang diucapkan tokoh Suhita di atas hanya sebuah ungkapan.

Data kedua adalah gaya bahasa kiasan simile. Penggunaan kata seperti menunjukkan bahwa tokoh di atas sengaja menyamakan dirinya dengan tokoh Bagus Burham dan istrinya. Konsep utama pada gaya bahasa simile adalah membandingkan dua hal yang pada hakikatnya berlainan, tetapi dianggap sama dengan menggunakan kata seperti, laksana, bagaikan. Perbedaan tersebut dijelaskan pada halaman-halaman selanjutnya, yakni kisah Bagus Burham yang tidak sesuai dengan kisah tokoh Suhita dalam cerita novel tersebut. Oleh sebab itu, kata seperti yang digunakan dalam data di atas menunjukkan gaya bahasa kiasan simile.

\section{Data 3}

"Seperti Lady Grey, seorang ratu Kerajaan Inggris yang berkuasa hanya sembilan hari lalu hidupnya berakhir dengan tragis. Kalau sudah begitu, aku berpikir sedih ini tidak ada apaapanya”. (Anis, 2019: 181).

Data (3) selanjutnya adalah gaya bahasa simile atau perumpamaan. Petikan dialog tersebut menunjukkan persamaan keadaan yang dirasakan tokoh Suhita dengan Lady Grey, Ratu Kerajaan Inggris yang berkuasa dan meninggal secara tragis. Persamaan tersebut jelas berbeda dengan keadaan yang dialami oleh Rengganis. Tokoh Rengganis hanya ditinggalkan orang yang ia cintai dan belum menikah. Oleh sebab itu, konsep simile yang dijelaskan hanya merujuk kepada penggunaan kata seperti, namun sejatinya cerita dari kedua tokoh tersebut berbeda.

\section{Data 4}

"Dia juga pernah uring-uringan karena aku memakai celana panjang warna sawo matang, sebab mirip warna kulit." (Anis, 2019:238).

Selanjutnya data (4) adalah gaya bahasa simile atau persamaan. Simile atau persamaan adalah membandingkan dua hal yang pada hakikatnya berlainan, tetapi dianggap sama dengan menggunakan kata seperti, laksana, bagaikan. Pada ungkapan celana panjang warna sawo matang dan warna kulit merupakan dua hal yang berbeda. Satu adalah pakaian, kedua adalah anggota tubuh yang dimiliki manusia. Namun, persamaan dari keduanya adalah sama-sama memiliki warna cokelat. Gaya bahasa simile ditunjukkan oleh kata mirip atau seperti atau bagaikan.

\section{Data 5}

"Semua orang berbahagia, aku pergi jauh sebelum kusaksikan mereka berdua benar-benar menjelma pengantin yang bahagia seperti Kamaratih Kamajaya”. (Anis, 2019: 242).

Data (5) berupa gaya bahasa simile atau persamaan, yakni membandingkan atau menyamakan dua hal yang pada hakikatnya berlainan. Hal itu dengan jelas dapat dilihat dari penggunaan kata seperti dalam ungkapan seperti Kamaratih dan Kamajaya.

Persamaan tersebut berdasarkan pada kisah cinta sejati yang dialami oleh sepasang suami istri, yakni tokoh pewayangan Kamaratih dan Kamajaya. Kisah cinta mereka kuat sehingga terkenal sebagai cinta sejati. Hal itu tentu berbeda sebab cerita yang sesungguhnya tokoh Gus Birru tidak mencintai Alina, tetapi masih mencintai Rengganis. Oleh sebab itu, konsep 
simile dari perbedaan yang sengaja disamakan dianggap sama dengan menggunakan kata bagaikan, seperti, dan laksana.

\section{Data 6}

Melihat mereka semua berbincang santai dan Rengganis tampak begitu diterima, hatiku yang sudah luka seperti ditabur garam lalu dibakar, meranggas benar-benar hancur di antara kami berdua. (Anis, 2019: 297).

Selanjutnya data (6) adalah simile atau persamaan. Simile merupakan perbandingan dua hal yang pada hakikatnya berlainan dengan menggunakan seperti, laksana, bagaikan. Data di atas adalah wujud simile sebab objek yang digunakan adalah hati dan garam. Keduanya merupakan dua hal yang berbeda, tetapi dianggap sama sebab keduanya dikaitkan menggunakan kata seperti.

Oleh sebab itu, hati yang terluka kemudian ditabur garam yang memiliki sifat basa akan menimbulkan rasa sakit yang mendalam. Perumpamaan digunakan pada petikan dialog tersebut untuk mencari kesamaan yang sejatinya berbeda dapat pula disebut sebagai personifikasi karena menggunakan kata seperti atau bagaikan sebagai unsur penguat pertama.

\section{Gaya Bahasa Metafora}

Gaya bahasa metafora hanya terdiri atas satu data berikut.

\section{Data 7}

"Kalau aku Ekalaya, hati Mas Birrulah mustika ampal itu, aku tidak akan membiarkan siapa pun merenggutnya dari hidupku atau hidupku akan siasia”. (Anis, 2019: 12).

Metafora dimaknai sebagai gaya bahasa yang membandingkan benda dengan benda lainnya karena memiliki sifat yang sama. Dalam kutipan di atas yang menunjukkan metafora adalah perbandingan hati dan mustika ampal, yakni sebuah benda berharga berupa batu milik Ekalaya. Pada dialog di atas hati tokoh Mas Birru dibandingkan sebagai mustika ampal yang harus senantiasa dijaga dan dirawat agar tidak lepas. Dua benda yang memiliki sifat sama, yaitu sama-sama memiliki nilai yang berharga, dapat dijadikan sebagai perbadingan satu sama lain. Oleh sebab itu, data di atas masuk dalam kategori gaya bahasa metafora.

\section{Gaya Bahasa Personifikasi}

Gaya bahasa personifikasi berjumlah dua belas data. Berikut analisisnya.

\section{Data 8}

"Aku tak mungkin bilang bahwa hidupku seperti diguyang ono blumbang, dikosoki alang-alang, disiakan, dan diabaikan." (Anis, 2019: 19).

Data (8) adalah bentuk gaya bahasa personifikasi, yaitu lebih pada melekatnya sifat-sifat manusia pada benda yang tidak bernyawa. Pada petikan dialog di atas perumpamaan yang diperlihatkan adalah tokoh Suhita yang menyamakan dirinya seperti benda yang diabaikan, dimandikan, dibersihkan dengan alang-alang, tetapi disia-siakan. Majas tersebut muncul sebagai penyamaan benda dengan manusia.

\section{Data 9}

"Alina suhita, sejak awal aku mengenalnya memang seperti kembang teratai. Dia mekar, tumbuh lurus di atas permukaan air tapi tidak tenggelam. Ia tegak seperti teratai meski kadang air itu berlumpur dan kotor ia tenang dalam keindahan." (Anis, 2019: 43). 
Pada data (9) gaya bahasa kiasan yang ditemukan adalah personifikasi. Majas pesonifikasi adalah melekatkan sifatsifat manusia terhadap benda karena memiliki sifat yang sama. Hal itu dapat dilihat pada ungkapan seperti kembang teratai. Kiasan tersebut diucapkan sebab ketanangan dan keanggunan yang dimiliki tokoh Alina Suhita sama halnya seperti bunga teratai. Penjelasan lebih lanjut mengenai ketenangan sifat yang dimiliki tokoh tersebut dengan bunga teratai ditandai dengan penjelasan $I a$ tegak seperti teratai meski kadang air itu berlumpur dan kotor ia tenang dalam keindahan.

\section{Data 10}

"Dialah sawo kecik yang berarti sarwo becik sebuah pengharapan agar selalu dalam kebaikan." (Anis, 2019:122).

Data (10) selanjutnya adalah personifikasi. Sawo kecik adalah jenis buah yang memiliki rasa manis. Sawo kecik tersebut kemudian dimaknai sebagai sarwo becik yang diartikan sebagai sebuah pengharapan dalam kebaikan. Sarwo kecik atau serba baik di sini merujuk kepada sifat-sifat manusia yang diharapkan selalu dalam kebaikan.

\section{Data 11}

"Juga mawar berarti mawi arso artinya kehendak niat, mengingatkan kita kalau melakukan sesuatu harus dengan niat yang kuat" (Anis, 2019: 122).

Data (11) adalah data personifikasi dengan penggunaan kata mawar, yakni bunga yang dimaknai sebagai mawi arso yang berarti kehendak niat, mengingatkan apabila melakukan sesuatu harus dengan niat yang kuat. Niat tersebut merujuk kepada sifat-sifat manusia yang tentunya memiliki niat setiap kali melakukan sesuatu. Kedua benda tersebut merupakan wujud personifikasi sebab keduanya melekatkan sifat-sifat menusia pada benda yang tidak bernyawa.

\section{Data 12}

"Kulihat kembang kenanga yang berarti keneng o gapailah. Kono zaman dulu tanaman seperti itu selalu ada di keraton sebagai pesan keneng o gapailah perilaku dan prestasi yang dipakai para leluhur" (Anis, 2019:123)

Data (12) masih berupa personifikasi. Data tersebut menggunakan benda berupa bunga kenanga yang dimaknai sebagai keneng o gapailah. Pemaknaan tersebut tidak terlepas dari filosofi dan budaya Jawa pada saat itu. Tanaman tersebut selalu ditanam di lingkungan keraton sebagai pesan bahwa keneng $o$ gapailah perilaku dan prestasi yang dipakai leluhur. Kalimat tersebut bermakna para penerus atau generasi muda harus mampu meniru perilaku dan prestasi para leluhur. Perilaku yang digunakan leluhur tentunya berbedabeda, di antaranya adalah teken, tekan, dan tekun. Majas personifikasi di atas menunjukkan sifat-sifat manusia yang kemudian dilekatkan pada sebuah benda berupa bunga kenanga.

\section{Data 13}

"Di sampingnya cempaka putih, biasa kita kenal dengan kembang kantil yang berarti kanti laku, dengan perbuatan. Ini mengingatkan kalau cita-cita lahir batin tidak hanya akan tercapai dengan memohon tapi sambil terus berusaha." (Anis, 2019: 123).

Data (13) berupa personifikasi. Konsep personifikasi adalah melekatkan sifatsifat manusia kepada benda-benda yang tidak bernyawa. Data di atas mengibaratkan benda berupa bunga cempaka putih yang dilekatkan pada 
sifat manusia, yakni tingkah laku dan perbuatan. Makna perbuatan itu sendiri adalah cita-cita lahir batin yang hanya akan tercapai dengan memohon dan terus berusaha. Filosofi bunga cempaka putih tersebut tidak terlepas dari para leluhur Jawa yang menerapkan prinsip tersebut dalam perbuatan atau tingkah laku mereka dalam menggapai cita-cita yang luhur.

\section{Data 14}

"Di sekitar kolam, kulihat kembang melati, melad soko jerone ati. Mengingatkan bahwa ucapan kita haruslah berasal dari hati yang paling dalam. Lahir batin harus serasi tidak munafik dan harus terus berprasangka baik” (Anis, 2019: 123).

Selanjutnya adalah data (14) yang berupa majas personifikasi. Majas tersebut adalah melekatkan sifat-sifat manusia pada benda-benda yang tidak bernyawa. Kembang melati yang kemudian dimaknai sebagai ucapan manusia haruslah berasal dari hati yang paling dalam, lahir batin dan tidak munafik atau memiliki prasangka tidak baik. Bunga melati yang digunakan adalah simbol agar manusia memahami maknanya dan menerapkan filosofi yang ada di dalamnya. Oleh sebab itu, majas tersebut masuk dalam kategori majas personifikasi.

\section{Data 15}

"Air mataku jatuh satu persatu ke pangkuan lalu kulihat di sudut tenggara halaman tertutup ini ada gerombolan tebu. Tebu adalah tanaman spiritual Jawa, dari kata antebing kalbu, kemantapan hati." (Anis, 2019: 124).

Pada data (15) tersebut penggunaan benda yang diumpamakan sebagai manusia adalah gerombolan pohon tebu. Pemaknaan pohon tebu tersebut adalah antebing kalbu atau hati yang kuat, kemantapan hati. Tanaman tersebut adalah salah satu tanaman spiritual Jawa yang dijadikan simbol pohon yang memiliki makna mendalam. Sifat manusia dengan kemantapan hatinya disimbolkan dengan pohon tebu tesebut.

\section{Data 16}

"Aku ingat kembang Wijaya Kusuma milik Prabu Kresna. Aku ingat Aji Pancasona milik Resi Subali. Aku ingat Mahaguru Sukra yang mempunyai Aji Sunjiwini. Ketiganya bisa menghidupkan semua yang sudah mati. Aku tidak tahu bagaimana lagi menghidupkan perasaanku." (Anis, 2019: 286).

Data (16) merupakan personifikasi. Personifikasi merupakan gaya bahasa kiasan yang dimaknai untuk melekatkan sifat-sifat manusia pada benda yang tidak bernyawa. Petikan dialog di atas menjelaskan bahwa perasaan manusia disamakan dengan benda-benda pusaka milik tokoh pewayangan. Di atas disebutkan bahwa beberapa tokoh memiliki senjata mustika yang dapat menghidupkan sesuatu yang sudah mati, seperti Kembang Wijaya Kusuma milik Prabu Kresna, Aji Pancasona milik Resi Subali, dan Aji Sunjiwini milik Maha Guru Sukra. Semua benda tersebut memiliki kesaktian yang dapat menghidupkan sesuatu yang sudah mati. Hal itu disamakan dengan perasaan tokoh Suhita yang tidak memiliki apaapa dan tidak mampu lagi menghidupkan perasaannya.

\section{Data 17}

"Di luar dugaanku, ternyata tamuku adalah Kang Dharma. Laki-laki yang selalu kubayangkan sebagai telaga. Dia adalah Kang Dharma, yang kuingat setiap kali resah menyergapku." (Anis, 2019: 304). 
Data selanjutnya adalah data (17) yang berupa gaya bahasa personifikasi, yakni melekatkan sifat-sifat manusia pada benda yang tidak bernyawa. Pelekatan sifat-sifat manusia di atas tergambar pada ucapan tokoh Alina yang mengatakan bahwa Kang Dharma dibayangkan sebagai telaga. Telaga adalah adalah danau kecil yang indah, jernih, dan tenang.

Air telaga dapat digunakan sebagai air minum dan menghilangkan rasa haus. Dalam konteks ini rasa haus diibaratkan tokoh Alina Suhita sebagai keresahan dan ketidakbahagiaan yang dialaminya. Oleh sebab itu, ia membayangkan Kang Dharma sebagai telaga yang dapat mengobati rasa hausnya tersebut.

\section{Data 18}

"Saat aku datang menemuinya, dia tersenyum. Senyumnya seperti oase di tengah padang sahara. Aku menunduk menyembunyikan haru." (Anis, 2019:305).

Data (18) selanjutnya masih mengenai personifikasi. Data di atas menunjukkan persamaan sifat manusia yang dilekatkan dengan benda, yaitu senyum dan oase di padang pasir. Senyum hanya dimiliki manusia. Senyum diibaratkan air yang terdapat di tengah oase atau daerah padang pasir. Air akan sangat bermanfaat dan dapat menghilangkan dahaga seseorang apabila ditunjukkan pada keadaan seperti di oase. Hal tersebut yang kemudian dilekatkan oleh tokoh Suhita kepada Kang Dharma.

\section{Data 19}

"Aku menatap Kang Dharma sekilas. Duh, mata itu selalu tenang seperti telaga. Dari sejak awal kami bertemu, hingga aku menikah, sampai detik ini sinar mata itu tidak berubah, tetap sama. tenang, teduh, damai. Seolah memastikan aku harus baik." (Anis, 2019: 309).

Data (19) masih membahas gaya bahasa personifikasi. Tokoh Alina Suhita kembali menyamakan tokoh Kang Dharma seperti telaga. Telaga yang dikenal dengan teduhnya, air yang tenang, dan jernih dilekatkan kepada Kang Dharma yang memiliki sifat teduh dan tenang. Penjabaran pada data di atas dapat dikategorikan sebagai data personifikasi.

\section{Gaya Bahasa Alusi}

Data alusi bejumlah enam data. Berikut adalah analisisnya.

\section{Data 20}

"Kamu itu cantik lin, dalam teori perempuan Jawa kamu itu menjangan ketawan." (Anis, 2019:22).

Data (20) adalah majas alusi. Konsep majas tersebut adalah bentuk ungkapan, peribahasa, atau sampiran pantun. Dalam petikan dialog di atas kalimat yang menunjukkan majas alusi adalah adanya peribahasa menjangan ketawan. Makna dari menjangan ketawan ialah ciri perempuan Jawa yang memiliki kekhasan wajah bulat, dahi tidak lebar, bibir seperti delima disigar, hidung kecil sedikit lancip, kulit langsat dan senantiasa basah, ramping, tinggi semampai. Namun, dalam hal ini, sisi lain dari kelemahan menjangan ketawan adalah apabila merasa sakit atau disakiti ia akan lari kencang dan tak menghiraukan siapa pun. Makna tersebut ditujukan pada tokoh Alina Suhita yang memiliki kecantikan dan sifat seperti menjangan ketawan.

\section{Data 21}

"Aku teringat ucapan Dewayani kepada Resi Sukra saat puteri Kerajaan 
Wrihaspara menghinanya. "luka yang disebabkan pedang dapat sembuh dalam perjalanan waktu. Tapi sakit hati karena kata-kata yang menusuk akan menggoreskan pedih selamanya." (Anis, 2019: 60).

Data (21) adalah alusi, yakni majas dengan ungkapan, peribahasa, atau sampiran pantun. Pada data di atas luka yang disebabkan pedang dapat sembuh dalam perjalanan waktu, tapi sakit hati karena kata-kata yang menusuk akan menggoreskan pedih selamanya" adalah bentuk ungkapan. Itu sebabnya ungkapan di atas adalah gaya bahasa kiasan berbentuk alusi.

\section{Data 22}

"Dulunya kupikir kisah cinta kami akan seperti bagus burham dengan istrinya raden ajeng gombang. Mereka berdua dijodohkan sejak kecil tapi mereka saling mencintai dan saling menginginkan sejak awal." (Anis, 2019: 69).

Data (22) mengandung dua gaya bahasa kiasan, pertama adalah gaya bahasa alusi dan kedua adalah gaya bahasa simile. Pada petikan dialog di atas tokoh Suhita mengatakan bahwa dahulu ia berpikir cintanya akan seperti Bagus Burham dan Ajeng Gombang yang dijodohkan sejak kecil, tetapi sudah saling menginginkan sejak awal. Kalimat tersebut dimaknai sebagai ungkapan tokoh agar kelak seperti tokoh lain, yakni Bagus Burham. Namun, keadaan justru membalikkan semuanya. Oleh sebab itu, berupa harapan yang diucapkan tokoh Suhita di atas hanya sebuah ungkapan.

Data kedua adalah gaya bahasa kiasan simile. Penggunaan kata seperti menunjukkan bahwa tokoh di atas sengaja menyamakan dirinya dengan tokoh Bagus Burham dan istrinya.
Konsep utama gaya bahasa simile adalah membandingkan dua hal yang pada hakikatnya berlainan, tetapi dianggap sama dengan menggunakan seperti, laksana, bagaikan. Perbedaan mengacu kepada kisah Bagus Burham yang tidak sesuai dengan kisah tokoh Suhita dalam cerita novel tersebut.

\section{Data 23}

"Kalau kami seromantis Wara Sumbadra dan Arjuna, yang saking mesranya sampai dijuluki mimi lan mintuna pastilah dalam sakitnya begini tak henti kupijat badan Mas Birru lalu kubenamkan hidungku dipipinya agar dia kelas sembuh." (Anis, 2019: 75).

Data (23) berupa alusi, yakni majas dengan ungkapan, peribahasa, atau sampiran pantun di dalamnya. Kalimat di atas menunjukkan alusi sebab tokoh Suhita mengungkapkan bahwa andai seperti Wara Sumbadra dan Arjuna pastilah ia akan melakukan hal yang sama. Kalimat tersebut hanya berupa pengandaian sebab ia menginginkan menjadi seperti tokoh Wara Sumbadra dan Arjuna.

\section{Data 24}

"Perempuan pengabsah wangsa, perempuan yang ideal yang menjadi wadah kesaktian dan penerus wangsa leluhur." (Anis, 2019: 148).

Data (24) adalah majas alusi. Data tersebut adalah bentuk dari ungkapan. Tokoh lain menjelaskan bahwa perempuan pengabsah wangsa dimaknai sebagai perempuan yang ideal yang menjadi wadah kesaktian dan penerus wangsa luhur. Ungkapan tersebut telah dikenal dalam filosofi Jawa. Majas tersebut masuk dalam kategori alusi sebab data yang ditunjukkan berupa ungkapan. 
Data 25

"Kulihat di antara mereka belum terbangun kedekatan. Tapi apa maksudnya kendito mimang, kadango dewo? Mimang adalah pikar pinang. Dia memang berbeda dengan akar tumbuhan manapun. Akar pinang bergerombol jadi satu, tidak melebar, bergerombol bertemu satu sama lain. kadango dewo berarti bersahabatlah dengan orang-orang suci. Mungkin berarti jangan gampang terpengaruh. Atau bisa bermakna mintalah petunjuk yang Maha Kuasa." (Anis, 2019:330).

Data (25) selanjutnya ialah alusi, yakni majas dengan ungkapan, peribahasa, atau sampiran pantun. Data di atas menunjukkan peribahasa yang sarat akan makna. Kalimat kendito mimang, kadango dewo dimaknai secara beragam, di antaranya adalah bersahabatlah dengan orang-orang suci, jangan mudah terpengaruh, dan yang terakhir adalah meminta petunjuk kepada Allah. Namun, dalam konteks cerita yang disajikan, peribahasa tersebut dimaknai sebagai permohonan petunjuk kepada Allah. Makna peribahasa yang terkandung dalam data di atas adalah nasihat.

\section{Gaya Bahasa Eponimi}

Terdapat enam gaya bahasa eponim yang ditemukan dalam novel.

\section{Data 26}

"Namaku Alina Suhita. Suhita adalah nama pemberian kakek dari ibuku. Ia ingin aku seperti Dewi Suhita. Perempuan tangguh yang pernah memimpin kerajaan besar Majapahit..." ( Anis, 2019: 4).

Data (26) yakni gaya bahasa kiasan eponimi. Konsep eponimi adalah gaya bahasa yang mengandung nama seseorang yang terlalu sering dihubungkan dengan sifat tertentu sehingga dipakai untuk menyatakan sifat tersebut. Dalam penggalan dialog di atas tokoh Suhita digambarkan sebagai wanita yang memiliki sifat tangguh dan hebat yang kemudian disamakan dengan tokoh Dewi Suhita sebagai ratu dari Kerajaan Majapahit yang terkenal dengan ketangguhannya.

\section{Data 27}

"Kadang merasakan sikapnya padaku, aku merasa seperti ekalaya, menanggung duka karena diabaikan dan ditolak guru drona." (Anis, 2019: 11).

Data (27) menyamakan sifat seseorang yang sudah terkenal dengan sifat tokoh dalam suatu cerita, yaitu Suhita disamakan dengan tokoh Ekalaya dalam pewayangan. Tokoh tersebut dikenal dengan ceritanya yang ditolak oleh gurunya Resi Drona untuk mengajari memanah. Penalakan tersebut menimbulkan pengabaian Guru Drona terhadap Ekalaya. Kepedihan yang dirasakan tokoh Suhita ialah penolakan yang dilakukan oleh suaminya sendiri. Ia menyamakan apa yang ia rasakan dengan yang dirasakan Ekalaya.

\section{Data 28}

"Dialah Kang Dharma yang tenang seperti Yudhistira. Banyak memberiku pengetahuan di tengah hapalanku yang padat. Yudhistira yang sabar dan berwatak samudera, yang mampu menguasai segala nafsu, yang mampu menerima segala watak dan kemauan orang lain. Yudhistira yang sangat mencintai istrinya" (Anis, 2019:18).

Data (28) selanjutnya ialah menyamakan sifat seseorang yang sudah begitu sering dihubungkan dengan sifat tertentu sehingga dipakai 
untuk menyatakan sifat tersebut. Tokoh Yudhistira terkenal dengan sifat sabar. Penegasan pada gaya bahasa eponimi terlihat pada penggunaan kata sifat sabar yang ditulis oleh penulis. Ketenangan Kang Dharma dalam novel tersebut disamakan dengan sifat Yudhistira yang memiliki watak tenang, sabar, berwatak samudera dan mampu menguasai segala nafsu.

\section{Data 29}

"Dialah sahabat yang sangat loyal dan baik. Dialah yang sering menghiburku di tengah tuntutan ketat untuk hapalan. Dia cantik dan lincah seperti banowati dalam pewayangan. Genitnya juga persis Banowati.” (Anis, 2019: 22).

Data (29) selanjutnya adalah gaya bahasa eponimi yang menyamakan sifat seseorang dengan sifat yang melekat pada tokoh yang biasa disebutkan karena terkenal akan karakternya. Pada data di atas tokoh Aruna disamakan dengan tokoh pewayangan yang bernama Banowati. Sifat yang melekat pada Aruna sama halnya dengan Banowati yang memiliki sifat lincah dan cantik. Begitu hanya dengan tokoh Banowati yang terkenal dalam pewayangan memiliki sifat lincah dan cantik rupanya.

\section{Data 30}

"Sampai kang dharma menjuluki kami seperti Niken Tambangraras dan Centini. Jelas aku Centini-nya." (Anis, 2019: 49).

Data (30) menghubungkan orang dengan sifat tertentu sehingga nama tersebut dipakai untuk menyatakan sifat tersebut. Petikan dialog di atas menunjukkan gaya bahasa eponimi sebab sifat utama yang melekat pada tokoh Centini ialah setia kepada Tambangraras. Centini adalah nama istri Syekh Amongraga, abdi setia Tambangraras. Kesetiaan tersebut kemudian disamakan oleh Kang Dharma seperti tokoh Aruna teman Suhita yang juga setia menemani Suhita ke mana pun dia mau. Sifat Aruna yang setia mendorong pengarang menyamakan sifatnya dengan tokoh Centini yang setia menjadi abdi Tambangraras.

\section{Data 31}

"Air muka Mbah Kung tampak tenang. Dan memang selalu tenang. Mbah Kung seperti Begawan Abiyasa, seorang pandhita yang tinggal di Pertapaan Wukoro Tawu, yang gentur tapane, mateng bratane, nyoto buntas kawruh lahir batine. Ketenangan tampak nyata di wajah, ucapan, dan seluruh tindakannya." (Anis, 2019: 299).

Data (31) mengandung nama seseorang yang begitu sering dihubungkan dengan sifat tertentu sehingga nama tersebut dipakai untuk menyatakan sifat. Data di atas lebih menggunakan sifat seseorang, yakni tokoh Begawan Abiyasa, yang dilekatkan atau disamakan dengan tokoh Mbah Kung yang sama-sama memiliki ketenangan.

\section{Gaya Bahasa Ironi}

Hanya ditemukan satu data ironi berikut.

\section{Data 32}

"Mana ini Rana Wijaya? Dia bertanya sambil tersenyum. Aku bingung maksud pertanyaannya sampai aku sadar Rana Wijaya adalah keturunan Dewi Suhita dia pasti bertanya apakah aku sudah hamil." (Anis, 2019:12).

Konsep ironi adalah sindiran halus yang apabila diucapkan tidak menimbulkan sakit hati pada penerima. Ironi yang 
terdapat pada data di atas adalah pertanyaan "mana ini Rana Wijaya?" Rana Wijaya adalah Raja Majapahit yang terakhir. Ia adalah anak dari Dewi Suhita. Kalimat di atas berbentuk sindiran halus yang ditujukan kepada Suhita, apakah sudah memiliki keturunan atau belum. Ungkapan tersebut tidak menimbulkan Suhita sakit hati sebab nada pengucapan yang dilontarkan sangat halus. Namun, meskipun halus, dasar dari gaya bahasa ironi tetaplah sindiran kepada orang lain.

\section{Relevansi Kajian Stilistika Berupa Gaya Bahasa Kiasan dalam Novel Hati Suhita sebagai Bahan Ajar di SMA}

Uraian dan analisis di atas diharapkan dapat dijadikan sebagai tambahan materi ajar bahasa dan sastra Indonesia oleh guru pada jenjang SMA. Adapun beberapa $\mathrm{KD}$ yang dapat dijadikan sebagai acuan atau referensi bagi guru Bahasa Indonesia di antaranya kelas XI dan XII, yaitu pada KD 3.9 Mengidentifikasi butir-butir penting dari dua buku nonfiksi (buku pengayaan) dan satu novel yang dibaca dengan nilai-nilai dan kebahasaan cerita rakyat dan cerpen. 4.9 Menyusun ikhtisar dari dua buku nonfiksi (buku pengayaan) dan ringkasan dari satu novel yang dibaca. KD 3.4 Menganalisis kebahasaan cerita atau novel sejarah, 4.4 Menulis cerita sejarah pribadi dengan memperhatikan kebahasaan. Selain itu, KD 3.9 Menganalisis isi dan kebahasaan novel, 4.9 Merancang novel atau novelet dengan memperhatikan isi dan kebahasaan baik secara lisan maupun tulis. Berdasarkan pada ketiga KD di atas hasil penelitian ini memiliki relevansi yang jelas dengan pembelajaran bahasa dan sastra
Indonesia di jenjang SMA. Kajian ini diharapkan mampu memberikan sumbangsih ilmu pengetahuan, menambah wawasan siswa mengenai kebahasaan yang berfokus pada kajian stilistika, yakni gaya bahasa pada novel. Selain itu, siswa memiliki bekal dan pengalaman mengenai gaya bahasa yang terdapat dalam sebuah karya sastra.

\section{PENUTUP}

Gaya bahasa kiasan yang ditemukan dalam novel Hati Suhita karya Khilma Anis ialah sebanyak 32 data yang terdiri atas 6 data gaya bahasa simile, 1 data metafora, 12 data personifikasi, 6 data alusi, 6 data eponimi, dan 1 data ironi. Gaya bahasa kiasan yang mendominasi adalah gaya bahasa personifikasi. Banyaknya data personifikasi ditandai dengan banyaknya petikan dialog yang melekatkan sifat-sifat manusia kepada benda yang tidak bernyawa. Beberapa di antaranya adalah tumbuhan yang dikiaskan dengan sifat-sifat manusia.

Secara keseluruhan, kekhasan gaya bahasa kiasan yang digunakan dalam berbagai bentuk perumpamaan dan perbandingan pada novel tersebut adalah tokoh-tokoh pewayangan dan peribahasa Jawa. Hal ini dilatarbelakangi biografi penulis yang gemar dunia pewayangan sejak kecil dan hidup di lingkungan pesantren. Khilma Anis sebagai penulis Hati Suhita adalah seorang ning yang hidup di lingkungan pesantren sehingga tidak heran karya-karya yang dihasilkan sarat akan budaya Jawa dan dunia pesantren.

Tiga KD yang berkaitan dengan penelitian yang dilakukan dapat dijadikan sebagai materi tambahan dalam pembelajaran bahasa dan sastra Indonesia. 


\section{DAFTAR PUSTAKA}

Abadiyah, S. (2020). Resolusi Konflik Perjodohan dalam Novel Hati Suhita Karya Khilma Anis. Jurnal Penelitian, Pendidikan Dan Pembelajaran, 15(24), 1-23.

Anis, K. (2019). Hati Suhita. Yogyakarta: Telaga Aksara.

Febrianto, D., \& Anggraini, P. (2019). Representasi Pewayangan Modern: Kajian Antropologi Sastra dalam Novel Rahvayana Aku Lala Padamu Karya Sujiwo Tejo. Jentera, 8(1), 1-15. https://doi.org/10.26499/jentera.v 8 i1.1192

Hawa, M. (2020). Analisis Tokoh dan Aspek Spiritual Quotient Novel Hati Suhita Karya Khilma Anis. Jurnal Educatio, 6(2).

Keraf, G. (2008). Diksi dan Gaya Bahasa. Jakarta: Gramedia Pustaka Utama.

Moleong, L. J. (2007). Metodologi Penelitian Kualitatif. Bandung: Remaja Rosdakarya.

Normalita, A., \& Hasanah, D. U. (2020). Analisis gaya bahasa dan nilai moral pada iklan layanan masyarakat di sepanjang jalan Solo-Ngawi. Salingka, 17(1), 89100.

https://doi.org/10.26499/salingka. v17i1.265

Nurgiyantoro, B. (2010). Teori Pengkajian Fiksi. Yogyakarta: Gadjah Mada University Press.

Pitriyani. (2017). Gaya Bahasa Kiasan dalam Novel Bulan Karya Tere Liye. STKIP PGRI Sumatera Barat.

Sardani, R., \& Indriani, S. (2018). Analisis Gaya Bahasa Kiasan dalam Berita Industri pada Media Digital Republika dan Media Indonesia. Jurnal Basis UPB, 5(1), 55-64. https://doi.org/10.33884/basisupb. v5i1.456 